\title{
Könyvszemle
}

SIPOS JÚLIA GONDOZÁSÁBAN

\section{A TITOK SZEMIOTIKÁJA}

Nem titok a Magyar Szemiotikai Társaság létezése: 1991 óta bírósági bejegyzés révén tevékenykedik. A jelekkel foglalkozó általános tudomány müvelöinek munkásságával (egyebek mellett) az immár félszáz szemiotikai tanulmánykötet révén is megismerkedhetett a hazai tudományosság. Ezeknek a kiadványoknak egy része az egri főiskola, majd egyetem támogatásával rendezett konferenciák anyaga.

Az sem titok, hogy a jeltudomány a filozófiával és a nyelvtudománnyal van kapcsolatban, ám módszerként az irodalomtudomány, a művészetelmélet, a néprajztudomány, továbbá a természettudományok nem egy ága (biológia, genetika stb.) alkalmazza.

Az egyének és a (társadalmi) csoportok életüknek, gondolkodásuknak sok vonatkozását valamilyen okból nem kívánják másnak vagy más közösségnek tudomására juttatni. Az okok számosak, kifejezéseink jól mutatják ezt: magántitok, államtitok, üzleti titok, gyónási titok, szolgálati titok, orvosi titok, családi titok, hadi titok és így tovább. Egy jel megfelelő használatához a szemantikai és szemiotikai szint ismerete szükséges, valamelyik hiánya titkot eredményez(het). Az Egerben 2018-ban megrendezett szemiotikai konferencia harminchárom előadásának kötete a titok tárgykörének irodalmi, nyelvi, pragmatikai, müvelödéstörténeti, kriminalisztikai, (szociál)pszichológiai, jogi, vallási és más vonatkozásairól ad képet az olvasónak. Ezt a tematikát öt csoportra bontották a szerkesztők, akik az előszóban hangsúlyozzák, hogy ,,[a] titok társadalmi meghatározottsága, szövevényes jellege miatt nem vizsgálható egyetlen szempontból. A titok jelensége különösen alkalmas antropológiai, azon belül szemiotikai, valamint multidiszciplinális megközelítésre" (8.).

Az első rész összefoglaló címe: Közösségi titkok, történetek. Az ide csoportosított tanulmányok témái már önmagukban jelzik, milyen széles terület jelenségeinek kutatása alkalmas szemiotikai vizsgálatra.

A titok antropológiájáról és szemantikájáról, kutatásáról, a társadalom és a titok viszonyáról ad eligazítást Balázs Géza. A jogi titok a témája Arató Balázsnak, aki a már említett üzleti titkot is taglalja. A 18. század Oroszországának 
fővárosában a szabadkőmüvességgel kapcsolatba hozható jelképek elemzésével foglalkozik Tóth Szergej, Újvári Edit okkult tanok, titkos társaságok jelképeiről ír (teozófiai emblémáról, rózsakeresztes iratok képeiről). A 17-18. század szürke eminenciásának, Richelieu-nek életútját, tevékenységét bemutatva a 'szürke eminenciás' jelentését-fogalmát igyekezik megadni Ortutay Katalin. A munkáskolóniákban élő férfiak és nők közötti titkok, elhallgatások antropológiai áttekintése a 20. század közepi világából R. Nagy József dolgozata. Terdikné Takács Szilvia a szent titokról, az eucharisztiáról mint jelelméletről értekezik, kitekintve a hittitokra. Az első rész utolsó tanulmánya: Kódfejtés - ex librisekbe zárt üzenetek. A könyvek tulajdonjegyeinek rejtett, titkos híranyaga abdukciós megfejtést tesz lehetővé Vasné Tóth Kornélia szerint.

A titok, mint az emberi alkotókészség eredménye címủ részben a néprajztudományban titokjeleknek vagyis tulajdonjegyeknek tulajdonságaival foglalkozik Gráfik Imre. Egy háromszéki község helyneveinek titkairól Már Orsolya, a térképek titkairól Tokaji Ildikó, a mesék titkairól Dallos Edina, a titkos testtetoválásról Szakál Eszter dolgozataiban lehet olvasni.

A titok a nyelvhasználatban összefoglaló fejezetcím első tanulmányában a hallgatás és az elhallgatás szemiotikájával foglalkozik Minya Károly. Hasonlóképp a nyelvi kommunikációs helyzet során képződő titkokat tárgyalja Dobi Edit. A személyiségzavar narcisztikus fajtájának szemiotikájába vezető írás Magyari Sáráé. Pölcz Ádám vizsgálata az enigmára mint megfejthetetlen titokra vonatkozik. A titkolózás nyelvi megvalósulásában egyes szófajok (névmások) szerepét taglalja Mayer Péter. A nem nyelvi, hanem a beszédet kísérő gesztusok szemiotikai viszonyai a témája Blankó Miklósnak. A beszéd, a megnyilatkozás egyes pragmatikai jelenségeire Tóth Áron Tamás hívja föl a figyelmet.

A titok irodalmi megjelenései témakörben $A$ névtelen vár címü Jókai-regényben lévő titokvonatkozások nyomait Voit Vilmos keresi, egy másik dolgozat az Ady Endre, Füst Milán és Karinthy Frigyes verseiben lévő titok szavai használatának alapján törekedik e költők életfelfogását (jobban) megismerni (Büky László). Hasonlóképpen az orosz avantgárd költészet megfejthető titkaira összepontosít Bagi Ibolya munkája. Kroó Katalin a titok megfejtésének szövegszemiotikai alapjaira hagyatkozva egyik Dosztojevszkij-regényéből hoz példákat. Még az iskolai olvasmányok titkairól is olvashatni (Veszprémi Eszter), a tündérmesék titkairól ugyancsak (Tuba Márta).

A modernség titkait vizsgáló tanulmányok a digitális identitás titkos jeleiről (Szirmai Éva), egy város látens bűnözésének kriminálgeográfiai vizsgálatáról, egy sorsdöntő első világháborús hadititokról (Deák-Sárosi László), a rockzene titkos vonatkozásairól (Márfai Molnár László), az ún. szabadulószobák rejtélyeiről (Horváth Zoltán), a média tabuiról és eufemizmusairól (Menyhért Dorottya), a lemezlovasok által fölhasznált zaj szerepköréröl (Horváth Márk és Lovász Ádám) szólnak. 
Ez a vázlatos áttekintés mutatja, hogy valóban szövevényes, a társadalomnak mint olyannak sok-sok jelenségében föllelhető a titok szerepe. A tanulmányok sora ezt igazolja, valamint azt is, hogy több tudományág kutatói találkoznak a titok jelenségével. A Magyar Szemiotikai Társaság érdeme, hogy közös mederbe, a szemiotikai szempontú vizsgálat medrébe igyekezett terelni a szerteágazó kutatások folyamát.

(Balázs Géza - Minya Károly - Pölcz Ádám szerkesztők: A titok szemiotikája. [Semiotica Agriensis 17] Budapest: Magyar Szemiotikai Társaság, 2019. 376 o.)

Büky László

nyelvész, egyetemi tanár 